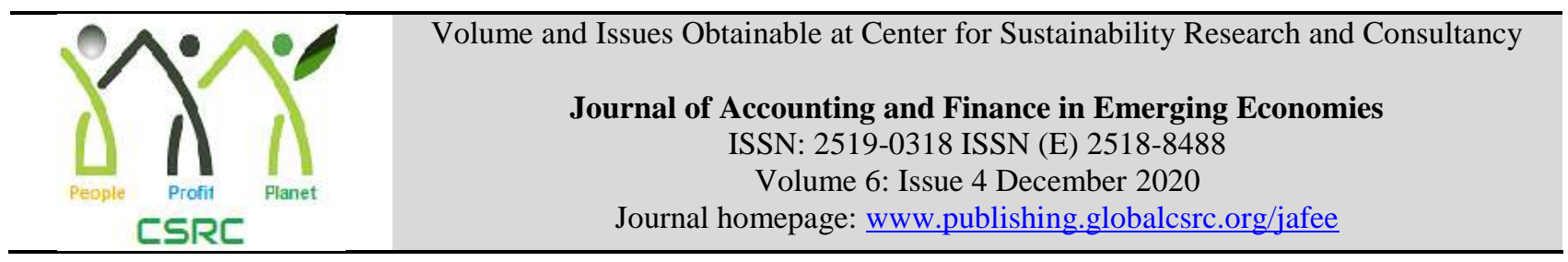

\title{
Impact of Pakistan Bait-Ul-Mal on the Satisfaction Level of the Beneficiaries
}

\author{
${ }^{1}$ Najma Sadiq, ${ }^{2}$ Ume Laila, ${ }^{3}$ Tahir Mehmood, ${ }^{4}$ Tooba Rehan Haqqi \\ ${ }^{1}$ Assistant Professor, Head of the Department, Department of Mass Communication, School of \\ Social Sciences and Humanities (S3H), National University of Sciences and Technology (NUST), \\ Islamabad, Pakistan, \\ najma.sadiq@s3h.nust.edu.pk \\ ${ }^{2}$ Assistant Professor, Government \& Public Policy, School of Social Sciences and Humanities (S3H), \\ National University of Sciences and Technology (NUST), Islamabad, Pakistan, \\ dr.umelaila@s3h.nust.edu.pk \\ ${ }^{3}$ Assistant Professor, Department of Communication studies, BahaUddin Zakariya University, \\ Multan, Pakistan, tahirmahmood@ bzu.edu.pk \\ ${ }^{4}$ Graduate Public Administration, Department of Government \& Public Policy, National University \\ of Sciences and Technology (NUST), Islamabad, Pakistan, Tooba.bpa16s3h@s3h.nust.edu.pk
}

\begin{tabular}{|c|c|}
\hline ARTICLE DETAILS & ABSTRACT \\
\hline History & This research $\mathrm{i}$ \\
\hline Revised format: November & impact the satisfaction level of the beneficiaries who are receiving \\
\hline 2020 Available Online: & funds and are acquiring the different programs and services of \\
\hline December & Pakistan Baitul Mal, a public treasury. The focus of the study is to \\
\hline 2020 & services they are \\
\hline Keywords & ating on the satisfaction \\
\hline Satisfaction level, Baitul Mal, & on the primary and se \\
\hline Public Treasury, Marginalized & that a vast majority of people were \\
\hline $\begin{array}{l}\text { society, Pakistan, Public } \\
\text { Institution }\end{array}$ & $\begin{array}{l}\text { vided by beneficiaries and most of } \\
\text { have nositively impacted on their }\end{array}$ \\
\hline JEL Class & this study has also provided some \\
\hline M48, M49 & $\begin{array}{l}\text { recommendations through which the scope and working of } \\
\text { organization can be enhanced. }\end{array}$ \\
\hline
\end{tabular}

Corresponding author's email address: tahirmahmood@bzu.edu.pk

Recommended citation: Sadiq, N., Laila, U., Mehmood, T. \& Haqqi, T. R. (2020). Impact of Pakistan Bait-Ul-Mal on the Satisfaction Level of the Beneficiaries. Journal of Accounting and Finance in Emerging Economies, 6(4), 995-1004

\section{Introduction}

It is disconcerting to know that around 24\% of Pakistan's civilians live below the poverty line (Pakistan, 2019). The Islamic Republic of Pakistan is a low to middle income nation that is situated at the intersection of south-central Asia. The total population of the country is 216 million, making it the fifth most populous country in the world. Nearly $60 \%$ of the nation's, $796,095 \mathrm{~km} 2$, land is arid to semi-arid (ADB, 2005 ). One third of its population is involved in the service sector while almost $50 \%$ is employed in the agriculture division (GoP, 2002). Agriculture is the significant sector in Pakistan with 
more than two-thirds of the population dwelling in rural zones. In order to curb these poverty crisis almost all of the countries have established welfare organization/ public treasuries. In Islamic terms these public treasuries are called as Bait-ul-Mal. The Bait-ul-Mal was traditionally a financial institution responsible for tax administration in Islamic states, particularly in the early Islamic Caliphate. It served as a royal treasury for the caliphs and sultans, handling personal finances and government spending. Additionally, it managed the distribution of zakat revenues for public services. Modern Islamic economists believe this social structure to be appropriate for Islamic

societies of today. One such Islamic public treasury has had been established in Pakistan with the name called "Pakistan Bait-ul-Mal". The head office of the Bait-ul-Mal is in Islamabad and there are 7 provincial offices in each province's capital, in Multan, Azad Jammu and Kashmir, and in Gilgit. For its service requirements, more district offices are established for efficient management and administration. The Bait-ul-Mal head office and all its branches and district level offices throughout the country are now interlinked through the Internet. This has been done to ensure full accountability and to improve efficiency in the organization.

This study aims to assess the beneficiary's satisfaction regarding PBM services, we have focused on its four services. These services are education, health, poverty and disability assistance. However, we have considered its other services as well, that includes, marriage and shelter. These are the new services introduced by the PBM, so there was not much information regarding them in the PBM database. We have measured these services through the inputs that were being provided by the PBM for the respective service. For the health, we assumed that PBM gave the medical card, cheques, cash transfers and treatment. However, our study indicates that PBM provides cheques and treatment for health purposes. For disability assistance, only cheques were provided. We considered that PBM provides a stipend, direct cash, scholarships and cheques for the education. However, our analysis proved that PBM provides scholarship and cash transfers to the students, which goes directly to their respective educational departments. PBM provides grants for poverty.

These inputs help us to understand whether the given input or cash is enough and satisfactory for the beneficiaries and how they have impacted the social welfare and wellbeing of a beneficiary. They also help us understand whether these services resulted in curtailing the social and economic issues and needs of the vulnerable. We will also be using inputs to help us determine the institutional capacity of PBM and we will consider beneficiaries satisfaction to help us evaluate the effectiveness of PBM services.

\subsection{Research Limitations}

Although research was able to fulfill its basic aim and purpose, there were certain limitations which hindered the potential of study and that could not have been completely ignored. Firstly, we were not able to carry out field surveys due to the ongoing pandemic, which had posed a great hurdle to carry our research.

Secondly, it is also believed that the interviews are more prone to biasness than the questionnaires due to the human nature, also the difference in understanding might also lead to biased results which has been rightly pointed out by a researcher who says, "interviewers are human beings and not machines. Bias can be present in wording the questions and in the way, they are interpreting" (Selltiz, 1962).

\section{Literature Review}

Numerous researches have been conducted around welfare and its many aspects since the latter half of the $20^{\text {th }}$ century. While the research questions and results may vary, they all share some overlapping themes: Theories/Models, Education, Finance, Health Care, Service Delivery, Bait-ul-Mal/waqf, and Welfare in General. 
Beginning with approaches, as previously discussed, Pakistan's welfare approach is based on that of the Islamic welfare state. When it comes to other countries, we can see that previously the Nordic State Model, for a variety of reasons, saw Denmark as an ideal leader to bring about welfare development. (Stein Kuhnle 1978). Moreover, when looking at it from an education standpoint we can see that it varies across the Nordic countries and it is more akin to patterns than a single model. Also, it has been noted that different education systems world over has become standardized (Antikainen 2006). In conjunction with this, Social Work Theory has been used to analyze aspects such as curriculum and work conditions by conducting research on the DACUM or the Develop-A-Curriculum method (Martha Bragin et al 2014). Since then, Social Investment has also been recognized as a critical approach and framework when it comes to welfare (Thomas Leoni 2016).

When it comes to service delivery, one of the earliest studies conducted is a critique on essential care packages which suggests that key services need to be improved, especially at a primary level and better financial management needs to take place to see significant improvements (Tim Ensor et al 2002).It has been noted that areas with high ethnic diversity receive less public provision than others (Jhumur Sengupta and Debnarayan Sarkar 2011). Accordingly, higher-income groups receive better service with the government needing to focus on protecting the vulnerable groups and eliminating poverty overall (Giang Thanh Long 2012). looking into support for the elderly and aging demographics research assesses the nations plan to tackle this issue (M. Nazrul Islam, Dilip C. Nath et al 2012). Researchers have suggested that the public has lost faith due to lack of standardized and high-quality public service (Femi Otomoso 2014). Furthermore, lack of planning and ineffective management has also contributed to poor service delivery (Moses Khisa 2015). A specific example of this aspect has to with water service delivery where it is found that public officials are self-interested, there is a lack of participation from consumers/employees, non-compliance with system accountability, and decline in water service provision. (John Mary Kanyamurwa 2016).

Studies have also investigated the legal constraints when it comes to the Bait-ul-Mal, researchers note that it has the potential to be improved further and thus would result in increasing economic activity (Bayu Taufiq and Possumah Abdul Ghafar Ismail 2012). When it comes to assessing the Bait-ul-Mal in federal territories, one study suggested that existing distribution methods are inadequate and that relevant laws need to be amended for it to operate at maximum efficiency (Liyana Al-Hany Binti Abdul Halim 2014). Additionally, Waqf is very important and it encourages social entrepreneurship to increase competitive advantages (Martha Bragin et al 2014). Waqf is also considered to be a great opportunity for less well-off families to receive proper education, funding, etc. (Muhammad Tariq Khan 2014). One study suggests that there should be increased efforts to generate Bait-ul-Mal funds to ensure its survival and to do so, private sectors need to be involved (Md. Habibur Rahman 2015).

\section{Research Methodology}

This is an empirical study, based on both primary and secondary sources of data. The framework of analysis on which primary data i.e. survey has been conducted is that how well beneficiaries know about the institution i.e. Bait-ul-Mal and how are they acquiring benefits. Moreover, interviews shall also be conducted to get to know the stance of the officials. Secondary data has been collected from the Institution regarding the beneficiaries so that we get a way forward in our research.

\subsection{Problem Statement}

The research aims to assess the impact of services of Pakistan Bait-ul-Mal on satisfaction of beneficiaries.

\subsection{Research Objective}

To determine the efficiency/effectiveness of the Bait-ul-Mal services on beneficiaries' satisfaction

\subsection{Research Question}

What is the impact of the Bait-ul-Mal on the satisfaction level of the beneficiaries? 


\section{Research Analysis}

For analyzing quantitative data, Interval Regression method was used. The aim behind using this technique was to evaluate the relationship that exists between the dependent and independent factors under study. For instance, interval regression method had been helpful in developing a relationship between satisfaction of beneficiaries who happen to be dependent on this research and the services and programs, which are independent variables, regarding to what extent they benefited the recipients. In social science, it is a common phenomenon that out of the large population a small fraction of data is collected and an inference is drawn for the whole population (Hamilton, 1992). Hence, this method reduces the probability and possibility of error that might exist in the general assumptions made. The quantitative data obtained through surveys was consolidated into an excel sheet and this method was applied through STATA.

For this research study, qualitative data was analyzed by using the method of thematic analysis and content analysis. Thematic analysis is the method used to identify, analyze, and report different patterns in qualitative data. Thematic analysis consists of six phases and this method should not be taken as a linear model which means that going to the next step without completing the previous step. (Clarke, 2008). For the purpose of this research interviews were analyzed through thematic analysis. The notion behind using this was to create a link between what the officials of the Bait-ul-Mal have to say regarding the services they provide and what views the beneficiaries have regarding the services they received.

\subsection{Qualitative Analysis}

The findings from the telephonic survey questionnaire have been analyzed in the following sections along with which the tables representing significant or insignificant relationship has been shown. For the purpose of analyzing data quantitatively, different statistical tools such as Ms. Excel and Stata were used throughout the computation and analysis process. For the purpose of this study we used regression method in order to analyze the relationship that exists between independent and dependent variables. The telephonic survey was conducted randomly through the different beneficiaries. The survey had a total of65 questions, and we surveyed 155 respondents. The aim was to evaluate the satisfaction level of the beneficiaries quantitatively. For the purpose of this study we used 8 regression models which will be discussed one by one in the next sections.

All the 8 models utilized 4 different regressions with set of different independent variables. The steric signs reflect the level of significance between the dependent and independent variables. $\mathrm{X}^{* * *}$ reflects the value of $\mathrm{p}>0.05, \mathrm{X}^{* *}$ shows the value of $\mathrm{p}<0.05$ and $\mathrm{x}^{*}$ shows the value of $\mathrm{p}<0.01$. the values with no steric sign show insignificant relationship. Moreover, the negative sign or no sign shows the nature of relationship that exists between the variables and lastly below the coefficients in the parenthesis is mentioned the value of standard error.

\subsubsection{Overall Satisfaction Level of Beneficiaries}

In order to evaluate the satisfaction level of beneficiaries with the overall working of organization we kept satisfaction level as dependent variables and regressed it with different independent variables mostly pertaining to demographic factors. The following table shows the results.

Table 1 Overall Satisfaction Level

\begin{tabular}{|c|c|c|c|c|}
\hline \multirow{3}{*}{$\begin{array}{l} \\
\text { INDEPENDENT } \\
\text { VARIABLES }\end{array}$} & \multicolumn{4}{|c|}{ DEPENDENT VARIABLE } \\
\hline & \multicolumn{4}{|c|}{ OVERALL SATISFACTION } \\
\hline & 1 & 2 & 3 & 4 \\
\hline Age & $\begin{array}{c}-0.0071 * * * \\
(0.0218)\end{array}$ & & $\begin{array}{c}0.0678 * * * \\
(0.0327) \\
\end{array}$ & $\begin{array}{r}0.0467 * * \\
(0.0369) \\
\end{array}$ \\
\hline $\begin{array}{l}\text { Difficulty In Application } \\
\text { Process, }\end{array}$ & $\begin{array}{c}0.1669 * * * \\
(0.0387)\end{array}$ & & & \\
\hline
\end{tabular}




\begin{tabular}{|c|c|c|c|c|}
\hline Employment Status & $\begin{array}{c}-0.0056^{* * * *} \\
(0.00511)\end{array}$ & & & $\begin{array}{l}-0.044 * * \\
(0.0905)\end{array}$ \\
\hline $\begin{array}{l}\text { Difficulty During } \\
\text { Communication }\end{array}$ & $\begin{array}{l}1.788 * * * \\
(0.1862)\end{array}$ & & & \\
\hline Kind Of Service Availed & & $\begin{array}{c}0.186 * * * \\
(0.0525)\end{array}$ & & \\
\hline Service Usage Difficulty & & $\begin{array}{c}0.329 * * * \\
(0.1446)\end{array}$ & & \\
\hline Applying In Baitul Mal & & $\begin{array}{c}0.1439 * * * \\
(0.0897)\end{array}$ & & \\
\hline User Of PBM Service & & $\begin{array}{c}1.691 * * * \\
(0.308)\end{array}$ & & \\
\hline Gender & & & $\begin{array}{c}-0.6277 * * * \\
(0.2006)\end{array}$ & $\begin{array}{c}-0.626^{* *} \\
(0.224)\end{array}$ \\
\hline Household Income Monthly & & & $\begin{array}{c}0.00704 * * * \\
(0.025)\end{array}$ & $\begin{array}{c}0.0164 * * \\
(0.0288)\end{array}$ \\
\hline Distance & & & $\begin{array}{c}0.644 * * * \\
(0.1031)\end{array}$ & \\
\hline Household earning members & & & & $\begin{array}{c}-0.1991 * * \\
(0.1004)\end{array}$ \\
\hline
\end{tabular}

This table shows that all the sets of independent variables when regressed with the satisfaction level have a value of $\mathrm{p}>0.05$ except for the $4^{\text {th }}$ regression outcomes which have value of $p<0.05$. The results also illustrate that satisfaction level has negative relationship with the independent variables such as age, gender, and household earning members in all the regression outcomes. Remaining variables implies a positive relationship.

\subsubsection{Level of Satisfaction with the Poverty Alleviation Service}

In order to be more specific, we evaluated the satisfaction level of beneficiaries with the services. Firstly, we evaluated the poverty alleviation service. In this relation all the results turned out to be highly significant because most of the beneficiaries had lost their jobs amid COVID-19 and they were in dire need of the financial support. With the timely disbursement of the funds the beneficiaries were quite satisfied. From the table following the results can be seen.

Table 2 Poverty Alleviation Service- Satisfaction

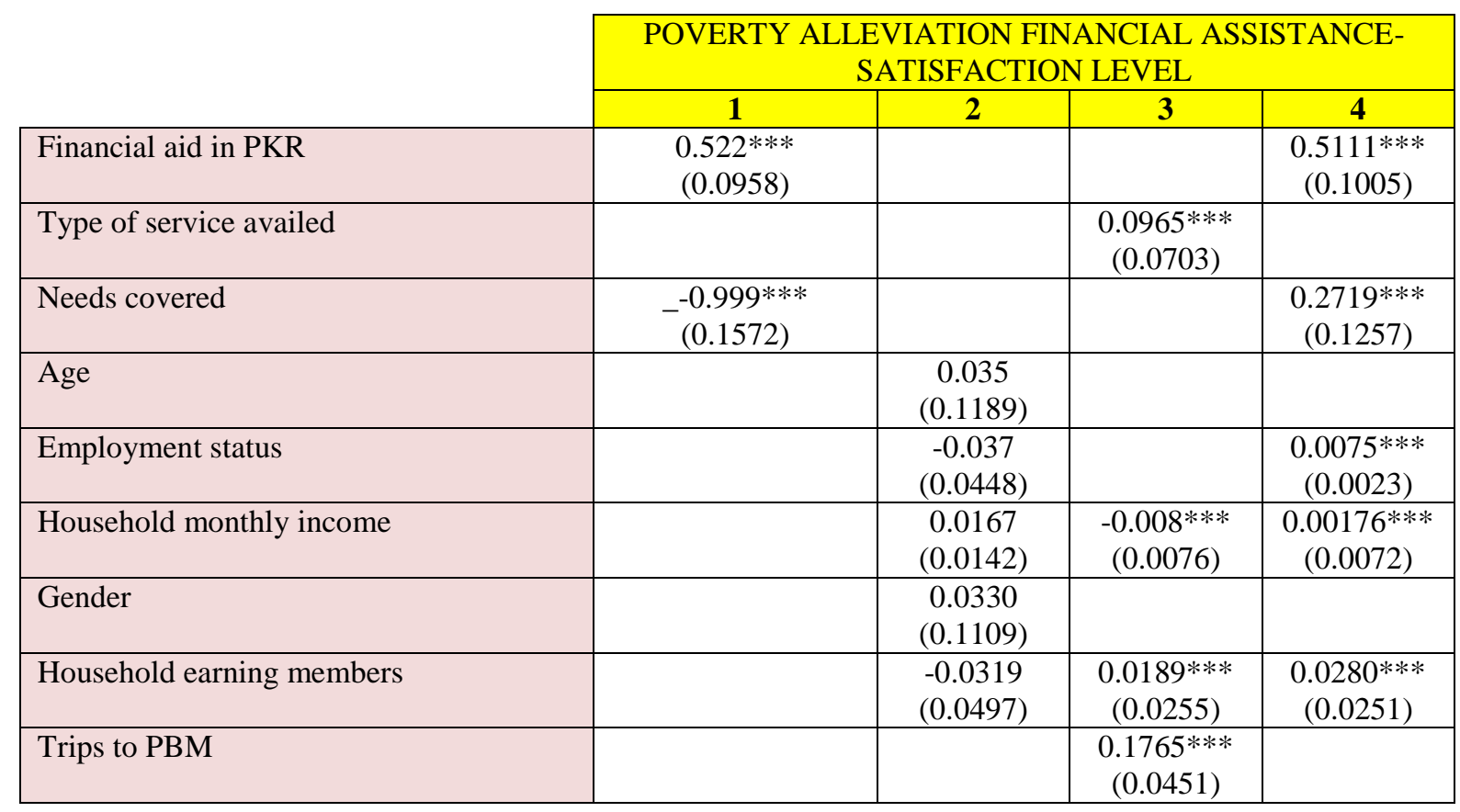




\begin{tabular}{|l|c|c|c|c|}
\hline Employment status & $0.0007 * * *$ & & & \\
& $(0.201)$ & & & \\
\hline Application process duration & $0.1432^{* * *}$ & & $0.235^{* * *}$ & \\
& $(0.0379)$ & & $(0.0258)$ & \\
\hline
\end{tabular}

All the values represent highly significant relationship with the dependent variables i.e. the value of p>0.05 in all the regression outcomes. Moreover, in this case needs covered, employment status, and household earning members reflect a negative impression on the dependent variable. Else apart from these it can be devised that all the independent variables are producing a corresponding change in enhancing the satisfaction level.

\subsubsection{Level of Satisfaction with the Medical Assistance Service}

Medical assistance is the most received and applied for service. People tend to acquire this service either because they do not have excess to the medical aid, or they are short of funds. The following table represents the results between satisfaction level and medical aid

Table 3: Medical Aid Satisfaction

\begin{tabular}{|c|c|c|c|c|}
\hline & \multicolumn{4}{|c|}{ MEDICAL AID- SATISFACTION LEVEL } \\
\hline & 1 & 2 & 3 & 4 \\
\hline Type of aid availed & $\begin{array}{c}1.215^{* * * *} \\
(0.1751)\end{array}$ & & $\begin{array}{c}1.1022 * * * \\
(0.2070)\end{array}$ & $\begin{array}{l}1.136 * * * \\
(0.2700)\end{array}$ \\
\hline nature of aid received & & $\begin{array}{c}3.774 * * * \\
(0.327)\end{array}$ & $\begin{array}{c}0.399 * * * \\
(0.3855)\end{array}$ & $\begin{array}{c}2.135 * * * \\
(0.435)\end{array}$ \\
\hline Employment status & & $\begin{array}{c}0.0239 * * * \\
(0.2269)\end{array}$ & & $\begin{array}{c}0.1863 * * * \\
(0.212)\end{array}$ \\
\hline Difficulty in applying & $\begin{array}{l}1.44 * * * \\
(0.1324)\end{array}$ & & $\begin{array}{l}1.354 * * * \\
(0.1483)\end{array}$ & \\
\hline Age & & $\begin{array}{c}-0.0445 * * * \\
(0.0969)\end{array}$ & & $\begin{array}{c}-0.094 * * * \\
(0.0897)\end{array}$ \\
\hline household income & & $\begin{array}{c}0.1108 * * * \\
(0.0768)\end{array}$ & $\begin{array}{c}0.1177 * * * \\
(0.0568)\end{array}$ & \\
\hline
\end{tabular}

The results again have revealed a significant impact on the level of satisfaction through the provision of these services except for one set of variables which include the regression 2. This relationship was highly insignificant hence showing that no such impact is demonstrated in this relationship. Else all other values had a positive relationship with $\mathrm{p}$ values $>0.05$.

\subsection{Level of Satisfaction with the Educational Assistance Service}

It was the second most demanded service. To check the level of satisfaction this service was creating we evaluated through 4 different relationships. All the values turned out to be highly significant i.e. $p=0.000$ which shows that these variables had enhanced the satisfaction level of the beneficiaries. The regressed results are accumulated in the following table.

Table 4: Educational Assistance Satisfaction

\begin{tabular}{|l|c|c|c|c|}
\hline \multirow{2}{*}{\multicolumn{1}{c|}{}} & \multicolumn{3}{|c|}{ EDUCATIONAL ASSISTANCE- SATISFACTION LEVEL } \\
\cline { 2 - 5 } & $\mathbf{1}$ & $\mathbf{2}$ & $\mathbf{3}$ & $\mathbf{4}$ \\
\hline Nature of educational assistance & $1.062^{* * *}$ & $-0.266^{* * *}$ & $1.216^{* * *}$ & $-0.327 * * *$ \\
& $(0.2174)$ & $(0.1256)$ & $(0.0738)$ & $(0.1300)$ \\
\hline Difficulty in applying & $0.103^{* * *}$ & & & $-0.0666^{* * *}$ \\
& $(0.110)$ & & $(0.0500)$ \\
\hline Improvement requires & & $4.172^{* * *}$ & & $4.303 * * *$ \\
& & $(0.2445)$ & & $(0.256)$ \\
\hline Education level & & & $0.0239 * * *$ & $(0.0305)$ \\
\end{tabular}




\begin{tabular}{|c|c|c|c|c|}
\hline Household earning members & & & $\begin{array}{c}0.0448 * * * \\
(0.0642)\end{array}$ & \\
\hline Household monthly income & & & $\begin{array}{c}0.0082 * * * \\
(0.0176)\end{array}$ & $\begin{array}{c}-0.0078 * * * \\
(0.0075)\end{array}$ \\
\hline employment status & & & $\begin{array}{c}0.0269 * * * \\
(0.0559)\end{array}$ & \\
\hline Biased selection criteria & & $\begin{array}{c}0.0496 * * * \\
(0.251)\end{array}$ & & $\begin{array}{c}-0.0707 * * * \\
(0.261)\end{array}$ \\
\hline Gender & & & $\begin{array}{c}-0.3055^{* * * *} \\
(0.1384)\end{array}$ & \\
\hline Stage of Acquisition & $\begin{array}{c}0.060 * * * \\
(0.351)\end{array}$ & $\begin{array}{c}-0.4887 * * * \\
(0.125)\end{array}$ & & $\begin{array}{c}-0.330 * * * \\
(0.1629)\end{array}$ \\
\hline
\end{tabular}

\subsection{Thematic Analysis}

\subsubsection{Satisfaction on Customer Service}

The data indicates that $66.94 \%$ of the respondents are highly satisfied with the services of Pakistan Baitul Mal. This is a huge number and indicates an efficient service delivery on the part of PBM. $16.53 \%$ and $5.79 \%$ respondents are moderately and slightly satisfied respectively. Overall, $89.26 \%$ of the respondents were satisfied with the services. Only $9.09 \%$ respondents were dissatisfied at different levels. Out of these only 2 respondents were extremely dissatisfied.

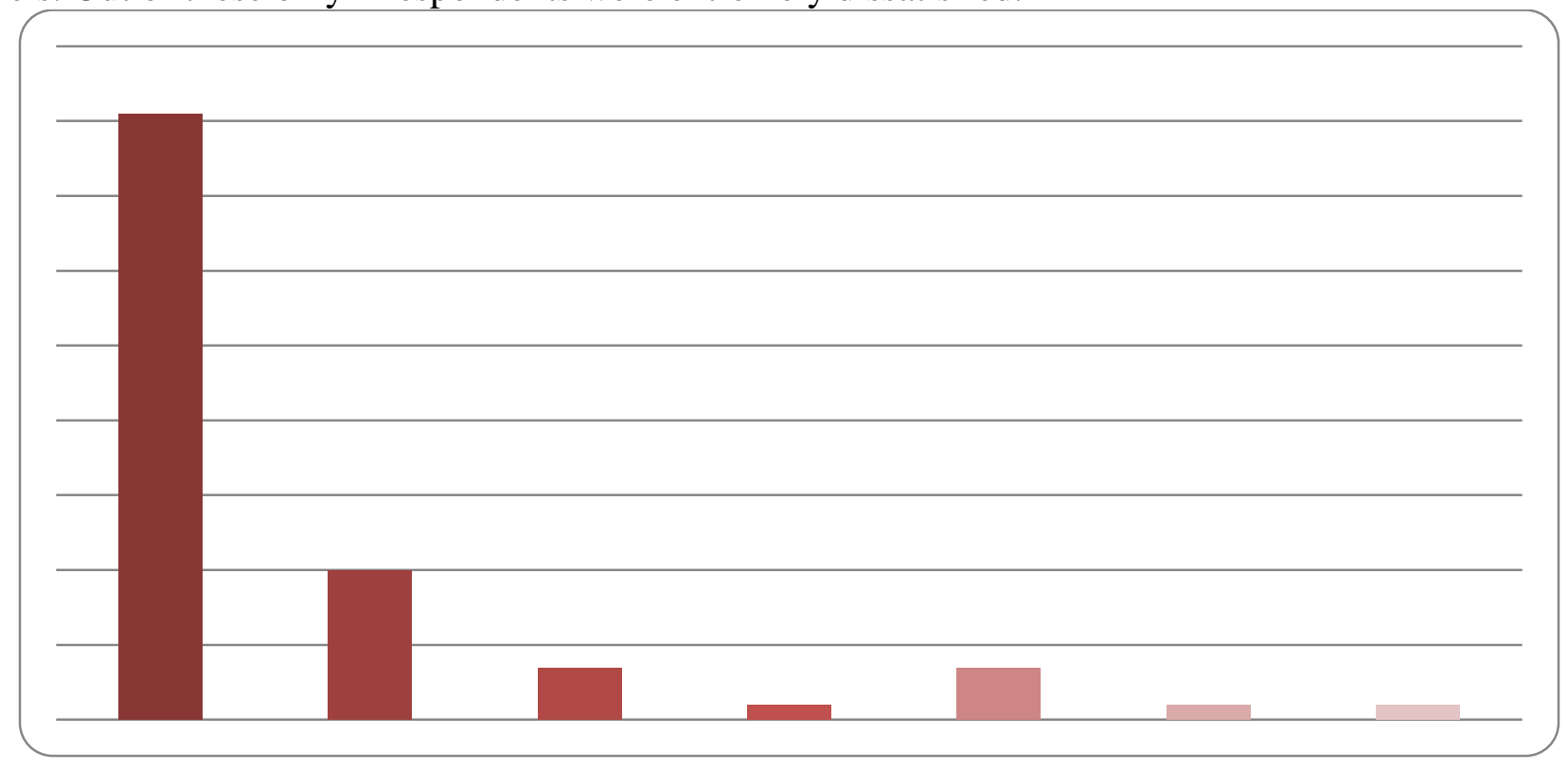

Figure 28 Level of satisfaction on customer service

\subsubsection{Level of Satisfaction with Poverty Alleviation}

The majority of the interviewed PBM beneficiaries seem to indicate that they are pleased with the grants that they receive, with over $51.85 \%$ of them stating that they are 'extremely satisfied' with them. Only, $11.11 \%$ expressed some sort of minor grievance with the grants, while $0 \%$ expressed completely negative sentiments. These answers might be somewhat biased considering that the beneficiaries would not want to express dissatisfaction at the thought of their complaints leading to their grants being stripped. While anonymity was maintained throughout, Hawthorne effect might be a factor here. 


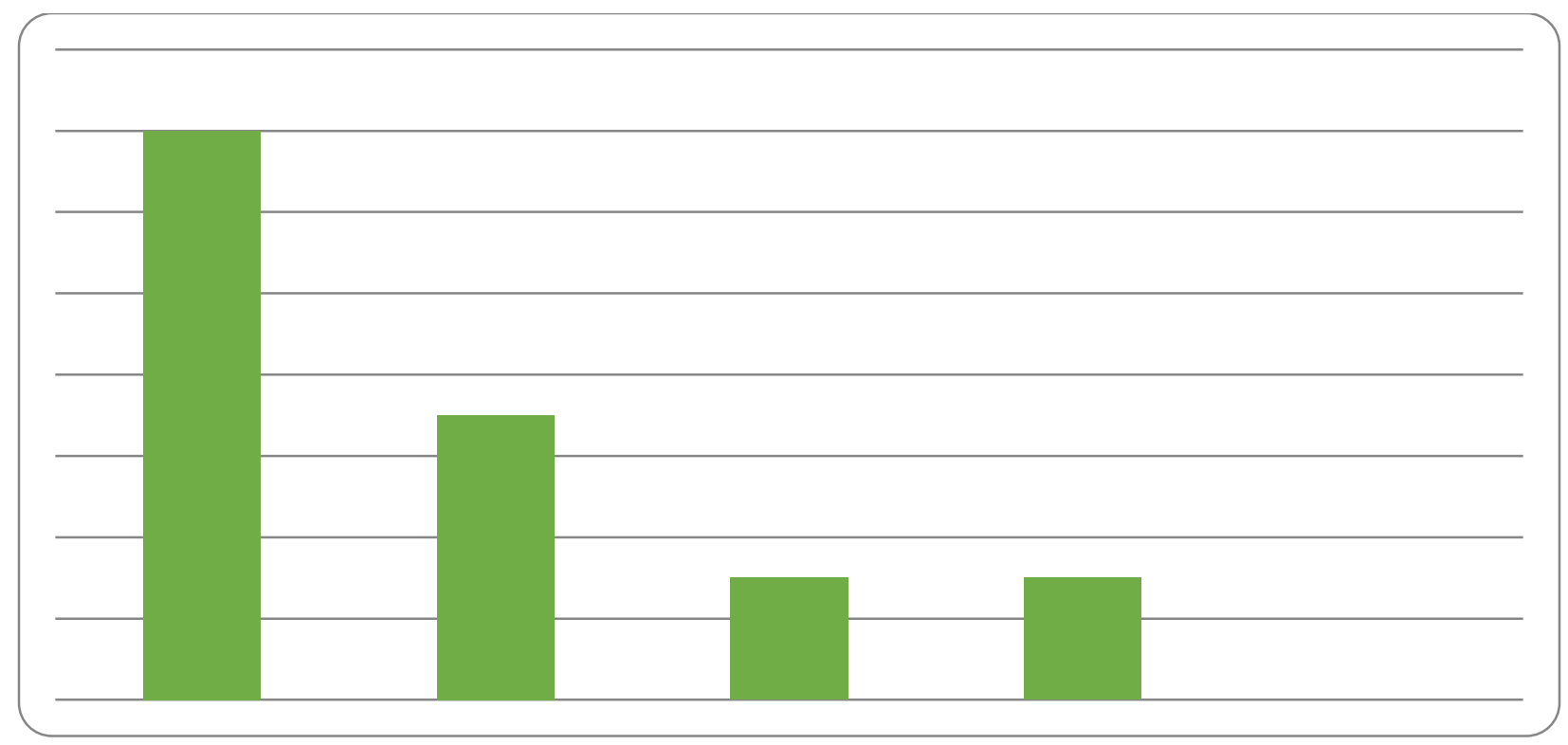

Figure 39 Level of satisfaction for poverty alleviation assistance program

\subsubsection{Level of Satisfaction with Educational Program Aid}

More than half of the respondents, $52.38 \%$, are extremely satisfied with the educational assistance program. There are $38.10 \%$ of respondents who are satisfied by it, and $9.52 \%$ have a neutral perspective about it. It implies that this program is effective in addressing the students concerns regarding education.

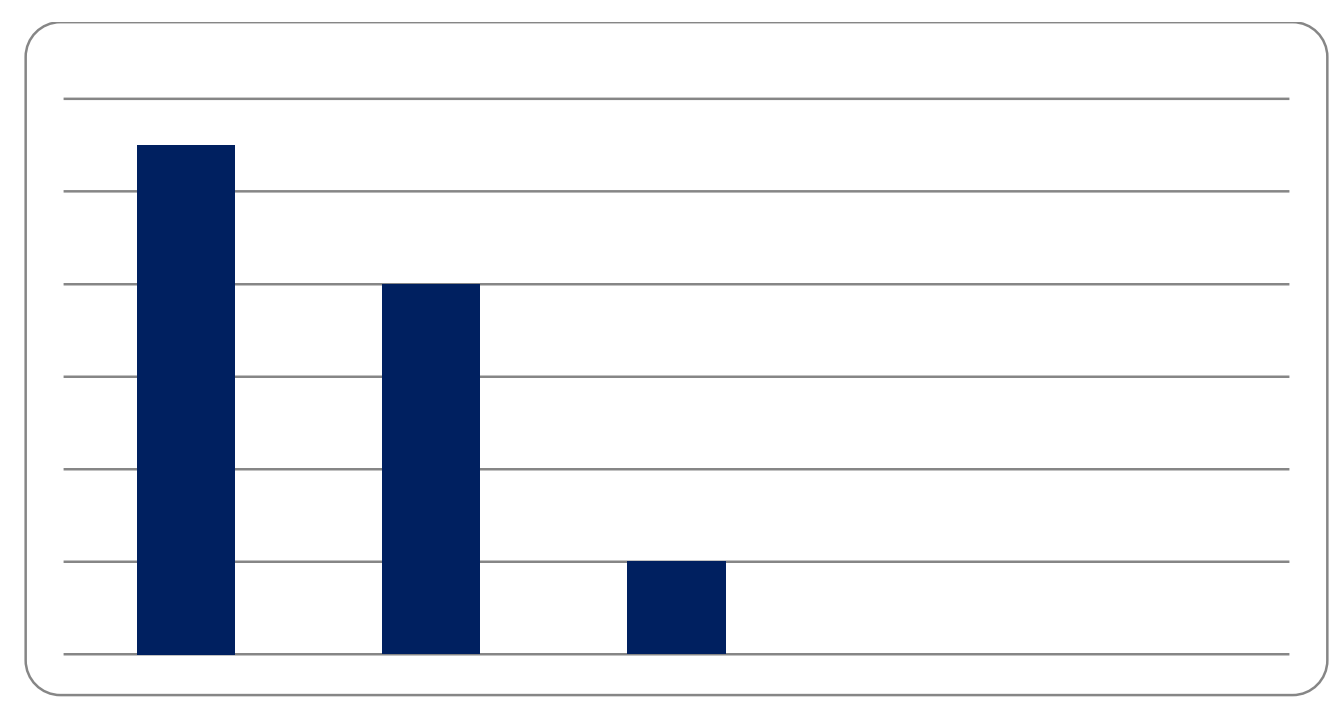

Figure 51 Level of satisfaction of educational assistance program

\section{Recommendations}

Positive dealing with the needs of the people is a major factor that influences the satisfaction of the people and as well as enhances the efficiency of the organization. The term "beneficiary satisfaction" refers to all those factors that make the organization work and achieve greater gains on the part of the general public. The extent of the impact that PBM is creating surely depends upon the level and quality of services and programs it is providing. This research study has sought to identify whether the services 
are producing any sorts of impact or not. After a careful analysis of the literature review it turned out that further study must be conducted in this area in order to identify major factors behind the working of the organization at optimum level. Due to limited availability of data only three services were analyzed deeply. In terms of satisfaction level of beneficiaries, a number of factors that influence the level of contentment among the recipients were studies. The demographic factors, employment related factors and application processing factors had mainly stimulated the level of satisfaction. The services had a momentous impact on the satisfaction of the beneficiaries. We couldn't gather enough data regarding employment relief but small grants to support household enterprises that generate just enough income to feed a belly were seen as useful. As far as the medical aid is concerned, slight dissatisfaction was recorded. They claimed that medical treatments were very costly and required urgent payment unnecessary delays in disbursements of the funds and mistreatment by the staff led to the grievances. The educational assistance had received a remarkable appraisal. The stipends issued to deserving students redounded to nothing but a fortune changer for the students. The stipends covered not just their living costs but also miscellaneous expenses that students face during their years in a college/university. Moreover, the students clearly mentioned that this service being provided by the PBM was free from any biasness and discrimination hence led to the enhanced gratification of the payees. Here our hypothesis has been proven.

\subsection{Anti-Corruption Cell}

The committee in charge of PBM should constitute an anti-corruption cell within the organization that would investigate complaints regarding misuse of authority and non-cooperation by the staff while maintaining a sharp oversight on overall proceedings and transactions. It should report directly to the parliamentary body responsible and not the management of PBM itself to render it autonomous yet vitally connected with it. Also, an audit report to the former ought to be submitted by this wing on an annual basis which would be scrutinized.

\subsection{Increasing Funds}

Running a nationwide social safety net with a stingy budget is an uphill task. Unfortunately, PBM is forced to stop receiving applications when its annual budget is depleted. I'm sure the government is giving it all it can afford but PBM itself should devise ways to generate its own revenue, whether it be by collaboration with INGOs, World Bank, UN organizations etc. or investing in sectors that would give profitable returns like bonds. These returns can be used to strengthen and uplift PBM financially so it can bring more beneficiaries in its net and improve its existing programs.

\section{Concluding Remarks}

In order to put end to this study, we believe that the findings of this research study and the recommendations will help the government of Pakistan to fully utilize the available resources and to serve the public by providing them improved and enhanced welfare services. not only that this research can also pave way for other public sector organizations to work efficiently and effectively because the fact cannot be denied that there exists a lot of potential here in Pakistan which if mindfully utilized will lead Pakistan to on the roads of prosperity. Pakistan Baitul Mal is close to the ideal model of social security provider for the country. Unlike other social security organizations or welfare programs, Pakistan Baitul Mal is working in quite an efficient manner with the least political environment. Government needs to bring the organization into the limelight and enhance its scope of service provision without politicizing it. Capacity building of the organization in terms of finances, particularly, holds the utmost importance in this regard. Moreover, an increase in the human resources is also very important to enhance the efficiency of the organization and provide a fast track service delivery to the applicants. Nascent welfare programs should be given under the umbrella of one institution to streamline the social safety net in Pakistan. This position should indeed be taken by the PBM considering the efficiency of organization and the trust of the public in the institution. 


\section{References}

Abu, T. K. (2014). Disaster Managment in Pakistan . Research Gate .

Adam, H. (2019, April 30). Financial Analysis- Random Sampling . Retrieved from Investopedia : https://www.investopedia.com/terms/s/simple-random-sample.asp

ADB. (2005 ). PovertY Line Analysis. Retrieved from Asian Development Bank : https://data.adb.org/dashboard

Anderson, C. (1979). Political Designs and Representation of Interest. In P. Schimitter, Trends towards corporatist Intermediation (pp. 73-145 ). Beverly Hills, CA: Sage Publications .

Bank, W. D. (2005). Developing Nations Analysis. WDR Reports.

Brunsson, N., \& Olsen, J. (1997). The Reforming Organization. Bergen: Fagbokforlaget. .

Clarke, V. B. (2008). Using thematic analysis in psychology. Qualitative Research in Psychology, 77101.

Dupuy, F., \& Thoenig, J. C. (1985). L'Administration en miettes. Paris: Le Seuil.

GoP. (2002). Labor statistics of Pakistan. Retrieved from Government of Pakistan .

Hamilton, L. C. (1992). Regression with Graphics: A second Course in Applied Statistics. pacific Grove.

Kondra, A., \& Hinings, C. (1998). Organizational diversity and change in institutional theory. In Organizational Studies (pp. 743-67).

mailman.columbia. (n.d.). Retrieved from Population of Health Methods: https://www.mailman.columbia.edu/research/population-health-methods/contentanalysis\#: :text=Content $\% 20$ analysis $\% 20$ is $\% 20 \mathrm{a} \% 20$ research,qualitative\%20data\%20(i.e.\%20te xt).\&text=Researchers $\% 20$ can $\% 20$ then $\% 20$ make $\% 20$ inferences,time $\% 20$ of $\% 20$ surrounding $\% 20$ the \%20text.

March, J., \& Olsen, J. (1975). The uncertainty of the past: organizational learning under ambiguity. European Journal of Political Research, 174-71.

March, J., \& Olsen, J. (1976). Ambiguity and Choice in Organizations. Bergen: Universitetsforlaget..

March, J., \& Olsen, J. (1984). The New Institutionalism: organizational factors in political life. American Political Science Review , 734-49.

Meyer, J., \& Scott, W. (1983). Organizational Environments: Rituals and Rationality. London: Sage .

Mohamed Elfil, A. N. (2017 ). Sampling methods in Clinical Research; an Educational Review. PubMed Central NCBI.

Pakistan, u. D. (2019). ReliefWeb. Retrieved from OCHA services: https://reliefweb.int/report/pakistan/multidimensional-poverty-pakistan

(2005 ). PMDGR. Pakistan Government.

Selltiz, C. (1962). Research methods in social relations . NewYorkRinehart and Wineston.

Selzinick, P. (1948). Foundations of The theory of Organizations . American Sociological Review, 2535.

Selzinick, P. (1949). TVA and Grass Roots . Bercley, CA . 